\title{
Sharing Informasi Pedoman Cuci Tangan Untuk Pencegahan Covid-19 Berbasis Sosial Media Di SD Negeri 88 Palembang
}

\author{
Reni Laili ${ }^{1}$, Leon A. Abdillah ${ }^{2}$, Evi Yulianingsih ${ }^{3}$, Iin Seprina ${ }^{4}$ \\ Universitas Bina Darma Palembang \\ renilaili@mail.binadarma.ac.id, leon.abdillah@binadarma.ac.id, \\ ev_yulianingsih@binadarma.ac.id,iin_seprina@binadarma.ac.id
}

\begin{abstract}
ABSTRAK
Teknologi Internet pada masa pandemi saat ini sangat dibutuhkan dan sangat membantu peradaban manusia melakukan semua aktivitas yang mengikuti protokol kesehatan yang diinstruksikan oleh pemerintah yaitu mulai dari social distancing, dilarang berkerumun, penggunaan masker, cara cuci tangan dan penggunaan hand sanitizer yang kesemuanya harus di taati demi menghambat penyebaran wabah virus corona ini. Salah satu cara untuk memutus rantai penyebaran virus Covid-19, dengan memberikan penyuluhan kepada Masyarakat khsusnya disekolah-sekolah untuk mengetahui pentingnya pedoman cuci tangan yang baik menurut WHO dengan menggunakan QR-Code agar lebih mudah dan efektif untuk mendapatkan informasinya melalui sosial media. Dari Kegiatan Pengabdian Masyarakat yang sudah dilakukan dapat disimpulkan bahwa Semua peserta lebih mengenal bagaimana mendapatkan informasi yang tepat terkait protocol kesehatan pencegahan COVID-19. Dengan menggunakan QR-Qode tentang pedoman cuci tangan, mereka mengetahui langkah-langkah mencuci tangan yang baik dan benara menurut WHO. Dalam pemanfaatan sosial media khususnya Guru-guru dan siswa dapat dengan mudah mencari informasi akurat terkait cara mencuci tangan sesuai dengan protocol kesehatan yang ditetapkan WHO.
\end{abstract}

Kata kunci : $Q R$-Code, $W H O$, Pedoman Cuci Tangan

\begin{abstract}
Internet technology during the current pandemic is very much needed and really helps human civilization carry out all activities that follow the health protocols instructed by the government, starting from social distancing, prohibited from gathering, using masks, washing hands and using hand sanitizers, all of which must be obeyed for the sake of prevent the spread of this corona virus. One way to break the chain of spread of the Covid-19 virus is to provide counseling to the public, especially in schools, to know the importance of good handwashing guidelines according to WHO by using a QR-Code to make it easier and more effective to get information through social media. From the Community Service Activities that have been carried out, it can be concluded that all participants are more familiar with how to get the right information regarding the COVID-19 prevention health protocol. By using the QR-Qode on hand washing guidelines, they know the steps for washing hands properly and correctly according to WHO. In the use of social media, especially teachers and students can easily find accurate information regarding how to wash hands in accordance with the health protocol set by WHO.
\end{abstract}

Keywords: QR-Code, WHO, Handwashing Guidelines 


\section{PENDAHULUAN}

Teknologi Informasi (TI) telah banyak digunakan untuk membantu beragam aktifitas manusia sehari-hari dan mengubah banyak perilaku dan kebiasaan (Abdillah, 2020a). Sejumlah tren di bidang TI antara lain, Social Media, Smartphone, Internet of Things (IoT), Big Data, dan Cloud Computing (Valacich \& Schneider, 2018). Sumber informasi tak hanya bisa didapat dari mesin pencari seperti Google atau mesin pencari lain, tapi juga berbagai media sosial. Teknologi Internet pada masa pandemi saat ini sangat dibutuhkan dan sangat membantu peradaban manusia melakukan semua aktivitas yang mengikuti protokol kesehatan yang diinstruksikan oleh pemerintah yaitu mulai dari social distancing, dilarang berkerumun, penggunaan masker, cara cuci tangan dan penggunaan hand sanitizer yang kesemuanya harus di taati demi menghambat penyebaran wabah virus corona ini. Dari hal inilah semua lembaga pendidikan dan sekolah diharuskan melakukan kegiatan pembelajaran menggunakan daring (Abdillah, 2020c).

Pada Akhir Tahun 2019, dunia dihebohkan oleh berita munculnya pandemi global yang disebabkan oleh virus corona secara tiba-tiba (Abdillah, 2020d). Virus corona jenis baru atau kemudian dikenal dengan sebutan COVID-19 (corona virus disease-2019) pertama kali mewabah di kota Wuhan Tiongkok. Virus ini mulai menyebar secara global atau menjadi pandemi pada 12 Maret 2020 (WHO, 2020). Untuk mencegah penyebaran wabah corona tersebut, maka pemerintah melakukan sosialisasi melalui media cetak, media sosial dan lain sebagainya.Persebaran wabah yang masih masif dan secara tiba-tiba membuat pemerintah harus sigap, efektif dan efisien dalam mengomunikasikan pencegahan wabah tersebut di masyarakat, agar masyarakat lebih waspada dan peduli terhadap wabah corona ini, terutama di sekolah.

Persebaran wabah yang masih masif dan secara tiba-tiba membuat pemerintah harus sigap, efektif dan efisien dalam mengomunikasikan pencegahan wabah tersebut di masyarakat, agar masyarakat lebih waspada dan peduli terhadap wabah corona ini,terutama di sekolah.Tak dimungkiri bahwa sejak ada internet, informasi menjadi sesuatu yang murah alias mudah didapat.Internet seakan menjadi lautan informasi. Sumber informasi tak hanya bisa didapat dari mesin pencari seperti Google atau mesin pencari lain, tapi juga berbagai media sosial.

Media Sosial adalah media yang paling efektif dalam menyampaikan informasi dengan cepat dan dapat di akses oleh semua usia kapan saja dan dimana saja. Hal ini lah yang membuat media sosial dijadikan alat untuk menginformasikan seputar cara 
pencegahan covid-19 antara lain dalam tata cara cuci tangan yang baik terlebih untuk siswa SD dan Para guru serta staf lainnya. Media sosial yang dapat digunakan dalam sharing informasi mengenai pedoman cuci tangan untuk pencegahan penyebaran virus covid-19 banyak sekali antara lain Facebook, Whatsapp, Line, Telegram dan Tweeter .Lebih lanjut, penelitian menunjukkan bahwa $60 \%$ dokter melihat media sosial sebagai jalan untuk memberikan layanan kesehatan yang lebih baik kepada pasien.Bagi pasien, media sosial adalah tempat untuk mendapatkan saran dari rekan-rekan yang mungkin mengalami masalah kesehatan yang sama. Mereka juga mencari saran untuk membuat perubahan gaya hidup dan solusi untuk masalah kesehatan yang mungkin mereka alami. Mereka berusaha untuk meredakan kekhawatiran tentang COVID dengan mengakses dan/atau membuat kontek media sosial tentang efektivitas gerakan cuci tangan menggunakan sabun guna membunuh virus COVID-19.

Berdasarkan latar belakang itulah, TIM PKM Universitas Bina Darma memandang perlu diadakan sharing informasi terkait pedoman cuci tangan yang baik (sesuai protokol kesehatan WHO) untuk pencegahan penyebaran virus covid-19 melalui media sosial khususnya di SD NEGERI 88 Palembang.

\section{METODE}

\section{A. Materi dan Bentuk Kegiatan}

Materi pada kegiatan ini adalah Sharing Informasi pedoman cuci tangan untuk pencegahan COVID-19 berbasis Sosial Media. Adapun proses pengumpulan dan penyusunan materi sebagai berikut.

\section{B. Bentuk Kegiatan}

Penyampaian Informasi berupa sharing atau pemaparan dan tanya jawab mengenai pedoman cuci tangan yang baik sesuai dengan yang sudah ditetapkan WHO dapat diakses melalui sosial media dengan menyertakan scan QR-Code pada informasi yang akan diakses oleh masyarakat. Agar masyarakat khususnya guru dan Siswa dapat mengetahui pentingnya pedoman cara mencuci tangan yang baik demi mencegah penyebaran virus COVID-19 dikalangan lingkungan sekolah. Kegiatan Pengabdian Kepada Masyarakat ini dilaksanakan selama 2 hari dengan melibatkan semua Dosen Tetap di Universitas Bina Darma sejumlah 4 personil. 


\section{HASIL DAN PEMBAHASAN}

\section{A. QR-Code}

“QR (Quick Response) codes” atau "QR-Code” atau kode batang untuk membaca suatu identitas.QR-Code adalah sebuah kode batang dua dimensi yang ditemukan oleh sebuah perusahaan Jepang bernama Denso Wave pada tahun 1994 (Lee, Kim, Lim, Jo, \& Lee, 2010).

Pada awalnya, teknologi QR-Code banyak digunakan pada stock inventory (Abdillah, 2020b). Label QR dapat ditempatkan pada work in process goods (WIP), raw materials (RM), dan finished goods products (FG) untuk memudahkan identifikasi SKU yang diberikan (unit penyimpanan unit) dalam hal jumlah bagian, jumlah, kode keterlacakan, dll (Avdekins \& Savrasovs, 2019).

Tabel 1. Daftar sosial media pedoman cuci tangan menurut WHO

\begin{tabular}{|c|c|c|c|}
\hline No & $\begin{array}{l}\text { Sosial } \\
\text { Media }\end{array}$ & Link & QR Code \\
\hline 1 & Youtube & $\begin{array}{l}\text { https://www.youtube.com/watch?v=cnWKh } \\
\text { ttte6c }\end{array}$ & \\
\hline 2 & Youtube & $\begin{array}{l}\text { https://www.youtube.com/watch?v=iOZJjF } \\
\text { Gy508 }\end{array}$ & \\
\hline 3 & Youtube & $\begin{array}{l}\text { https://www.youtube.com/watch?v=0yxWf } \\
\text { BgBNVk }\end{array}$ & \\
\hline 4 & Website & $\begin{array}{l}\text { https://health.detik.com/berita- } \\
\text { detikhealth/d-4903337/cara-cuci-tangan- } \\
\text { yang-benar-menurut-kemenkes-dan-who }\end{array}$ & 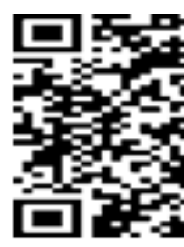 \\
\hline
\end{tabular}




5 Website $\begin{aligned} & \text { http://promkes.kemkes.go.id/flyer-6- } \\ & \text { langkah-cuci-tangan-pakai-sabun-ctps }\end{aligned}$

Banyak sekali sosial media yang menampilkan informasi tentang tata cara cuci tangan berdasarkan WHO baik dalam bentuk video maupun dalam bentuk teks di dalam website. Untuk menjadi edukasi bagi masyarakat agar dapat memahami dan mencontoh pedoman cuci tangan yang baik untuk mencegah agar penyebaran virus covid-19 tidak menyebar.Sebagai bentuk pemenuhan kebutuhan akan sharing informasi yang bermanfaat agar lebih efektif dan efisien digunakan QR-Code yang dapat di scan dengan mudah menggunakan handphone maupun alat scan QR-Code.

B. Sharing Information Menggunakan Standing Banner

Berbagai kegiatan berbagi informasi di media sosial, termasuk membuat posting, foto, dan video (Oh \& Syn, 2015). Informasi terkait pencegahan COVID-19 banyak beredar di masyarakat, namun belum tentu informasi-informasi tersebut benar dan sesuai dengan arahan WHO dan pemerintah. Agar informasi yang disebarkan efektif, maka tim PKM membagikan informasi terkait cuci tangan dalam bentuk "Standing Banner".

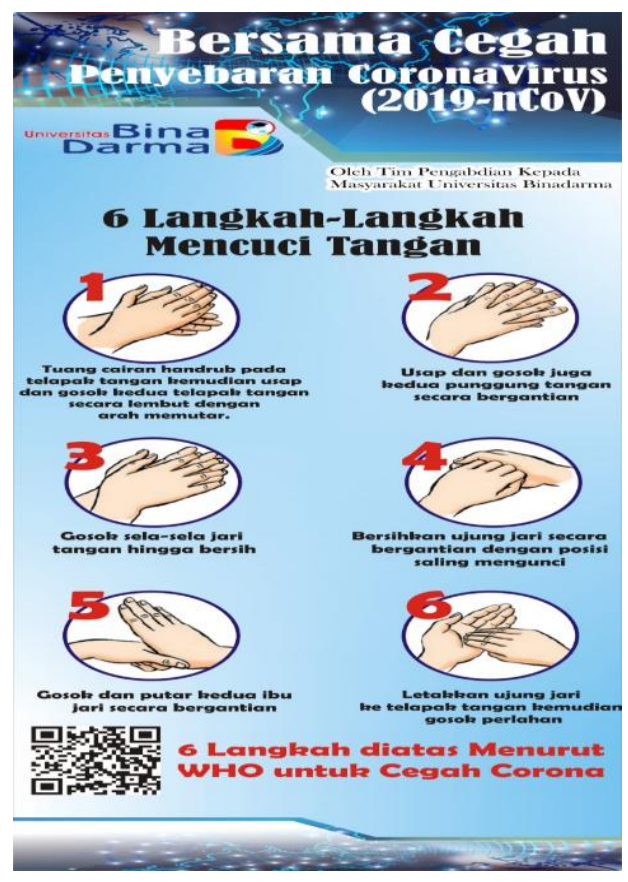

Gambar 1.Standing Banner dengan QR-Code 
Pada standing banner tersebut juga dilengkapi dengan QR-Code (Al Satrio, Abdillah, \& Syazili, 2017) yang terhubung dengan alamat YouTube Cuci Tangan versi WHO. Dampak dari kegiatan Pengabdian Kepada Masyarakat ini adalah memberikan pemahaman kepada masyarakat khususnya Guru -guru dan siswa mengenai pedoman cuci tangan yang baik menurut WHO.

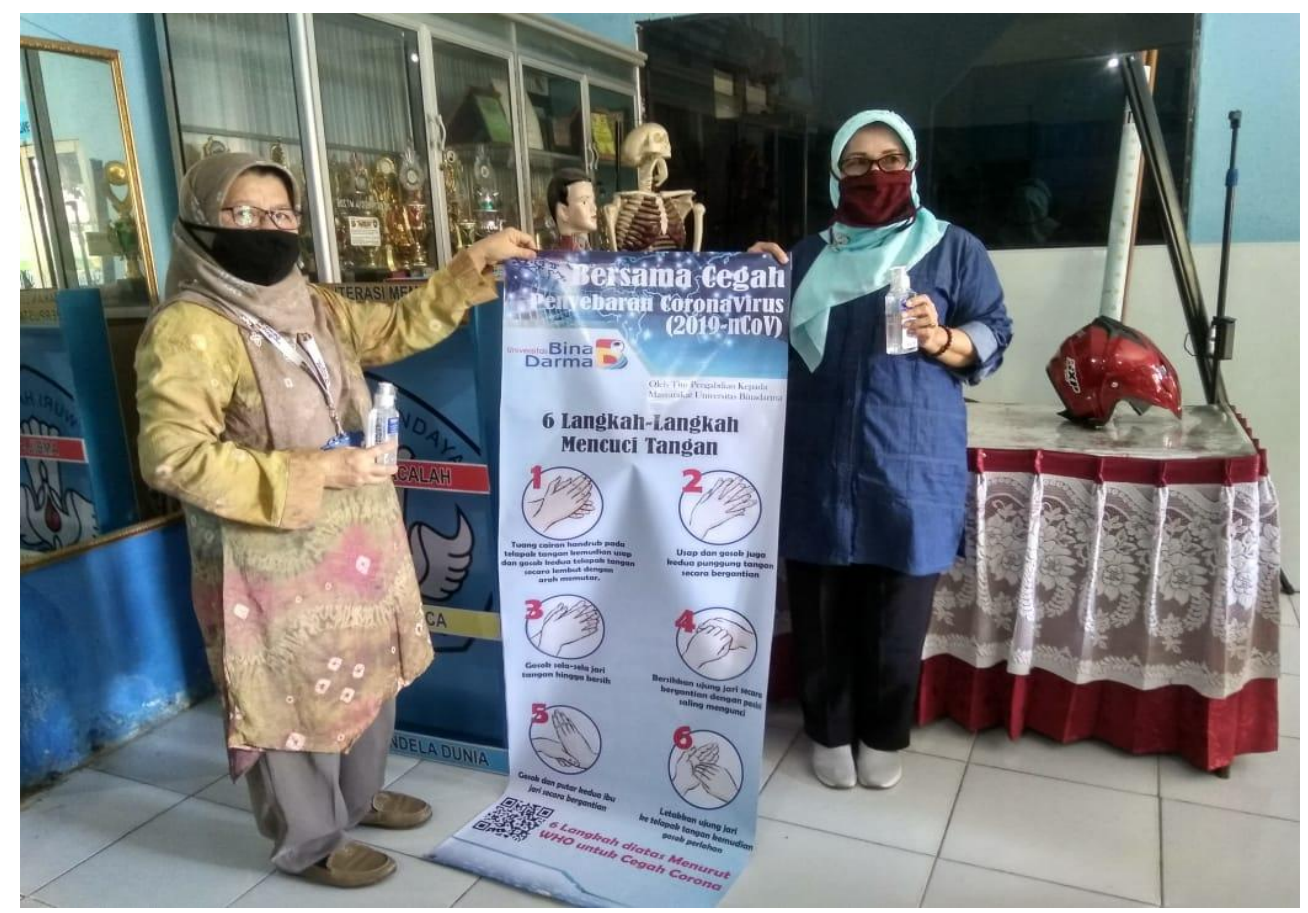

Gambar 2.Standing Banner dengan QR-Code

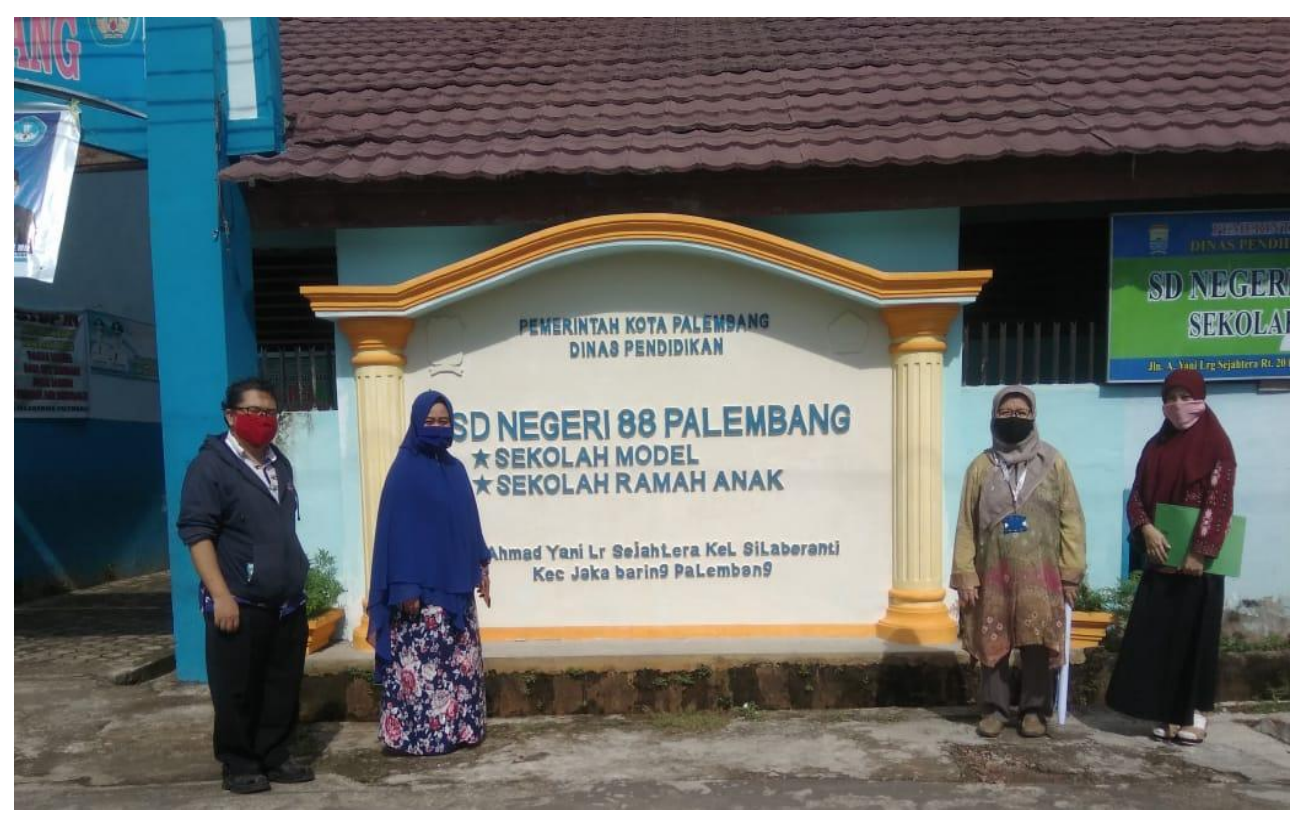

Gambar 3.Tim PKM Dosen 


\section{SIMPULAN}

Dari Kegiatan Pengabdian Masyarakat yang sudah dilakukan dapat disimpulkan bahwa semua peserta lebih mengenal bagaimana mendapatkan informasi yang tepat terkait protokol kesehatan pencegahan COVID-19. Dengan menggunakan QR-Qode tentang pedoman cuci tangan, mereka mengetahui langkah-langkah mencuci tangan yang baik dan benara menurut WHO. Pemanfaatan sosial media khususnya guru-guru dan siswa dapat mencari informasi akurat terkait cara mencuci tangan sesuai protokol kesehatan WHO.

\section{DAFTAR PUSTAKA}

Abdillah, L. A. (2020a). FinTech E-Commerce Payment Application User Experience Analysis during COVID-19 Pandemic. Scientific Journal of Informatics (SJI), 7(2), 265-278. https://doi.org/10.15294/sji.v7i2.26056

Abdillah, L. A. (2020b). Model Transaksi Keuangan Perdagangan Elektronik (ECommerce Financial Transaction Model). In Perdagangan Elektronik: Berjualan di Internet (Electronic Commerce: Selling on the Internet). Medan: Yayasan Kita Menulis.

Abdillah, L. A. (2020c). Online Learning Menggunakan Zoom Teleconference: Work Form Home During COVID-19 Global Pandemic. Retrieved from Computer Science and Information Systems website: http://eprints.binadarma.ac.id/4162/2/Abdillah2020 \%5BOnline Learning Menggunakan Zoom Teleconference\%5D 2020415.pdf

Abdillah, L. A. (2020d). Stigma Terhadap Orang Positif COVID-19. In Pandemik COVID19: Antara Persoalan dan Refleksi di Indonesia. Medan: Yayasan Kita Menulis.

Al Satrio, M., Abdillah, L. A., \& Syazili, A. (2017). Aplikasi Presensi Mahasiswa dengan Menggunakan QR Code Berbasis Android pada Universitas Bina Darma. Seminar Hasil Penelitian Ilmu Komputer Ke-2 (SENTIKOM2017). https://doi.org/10.17605/OSF.IO/NMHRX

Avdekins, A., \& Savrasovs, M. (2019). Design and prototyping of IoD shared service for small and medium enterprise. Advances in Intelligent Systems and Computing, 879, 823-830. https://doi.org/10.1007/978-3-030-02305-8_99

Lee, Y. S., Kim, N. H., Lim, H., Jo, H. K., \& Lee, H. J. (2010). Online Banking Authentication system using Mobile-OTP with QR-code. Proceeding - 5th International Conference on Computer Sciences and Convergence Information Technology, ICCIT 2010, 644-648. https://doi.org/10.1109/ICCIT.2010.5711134

Oh, S., \& Syn, S. Y. (2015). Motivations for sharing information and social support in social media: A comparative analysis of Facebook, Twitter, Delicious, YouTube, and Flickr. Journal of the Association for Information Science and Technology, 66(10), 2045-2066.

Retrieved

from https://asistdl.onlinelibrary.wiley.com/doi/abs/10.1002/asi.23320

Valacich, J., \& Schneider, C. (2018). Information Systems Today: Managing in the Digital World (8th ed.). New York, USA: Pearson Education, Inc.

WHO. (2020). WHO Director-General's opening remarks at the media briefing on COVID-19 - 11 March 2020. Retrieved from https://www.who.int/dg/speeches/detail/who-director-general-s-opening-remarks-atthe-media-briefing-on-covid-19---11-march-2020 